\title{
Investigation of the Anticancer Effects of Nanocomposite of the Modified Graphene Oxide with Isatin-3-Semicarbazone on the Retinoblastoma Cells (Y79) Invitro
}

\author{
Zahra Ramezani' $^{\text {iD }}$, Hasan Tahermansouri* ${ }^{*}{ }_{\text {1D }}$ Farhoush Kiani $^{1}$ \\ ${ }^{1}$ Dept of Chemistry, Ayatollah Amoli Branch, Islamic Azad University, Amol, Iran
}

\section{Article Info}

Article type:

Research article

Article History:

Received: 05 December 2020

Revised: 16 December 2020

Accepted: 03 June 2021

\section{* Correspondence to:}

Hasan Tahermansouri

Dept of Chemistry, Ayatollah

Amoli Branch, Islamic Azad University, Amol, Iran

Email:

h.tahermansuri@iauamol.ac.ir

\author{
A B S T R A C T
}

Introduction: The most common ocular tumor is retinoblastoma, which can be treated by different methods. The use of carbon nanostructures has attracted much attention due to their unique properties, such as crossing cell membranes, for cancer diagnosis and other medical applications. This study aimed to investigate and assess the toxicity of the modified graphene oxide (GO) with isatin-3-semicarbazone (ISA) in order to treat retinoblastoma.

Material \& Methods: This study utilized ISA to modify the GO. Subsequently, the modified GO-ISA was characterized by different techniques, such as Fourier transform infrared spectrometry, Scanning Electron Microscope, and Thermal Gravimetric Analysis. The cell toxicity of samples was assessed by MTT assay for two types of cells of retinoblastoma (Y79) and adipose-derived stem cells (ADSC) after $24 \mathrm{~h}$ at different concentrations. Data were analyzed in SPSS software using one-way analysis of variance (ANOVA). A p-value less than 0.05 was considered statistically significant.

Findings: The results showed that in the concentration range of $10-50 \mu \mathrm{L}$, GO-ISA decreased significantly $(\mathrm{P}<0.01)$ the conservation percentage of retinoblastoma cells from $73.98 \%$ to $27.48 \%$, while these values for ADSC decreased from $78.16 \%$ to $50.11 \%(\mathrm{P}<0.01)$. In addition, GO-ISA at $30 \mu \mathrm{L}$ resulted in a significant increase $(\mathrm{P}<0.01)$ in the cell toxicity of the retinoblastoma (26\%), compared to GO.

Discussion \& Conclusion: GO-ISA increases the toxicity of the retinoblastoma cells, compared to $\mathrm{GO}$ which was significant at $30 \mu \mathrm{L}$. Therefore, this modification of the surface can be useful in future applications. With this modification of the surface, the active sites are provided for the biological and pharmacogenetic reactions in future.

Keywords: Graphene oxide, Isatin, Retinoblastoma, Surface modification, Toxicity

$>$ How to cite this paper

Ramezani Z, Tahermansouri H, Kiani F. Investigation of the Anticancer Effects of Nanocomposite of the Modified Graphene Oxide with Isatin-3-Semicarbazone on the Retinoblastoma Cells (Y79) Invitro. Journal of Ilam University of Medical Sciences. 2022;29(5): 75-88. 
بررسى آثار ضد سرطانى نانو كاميوزيت تر افناكسايد اصلاحشده با ايزاتين - - - سمى كاربازون بر سلول هاى رتينو بلاستوما (Y79) در شرايط آزمايشكاهى

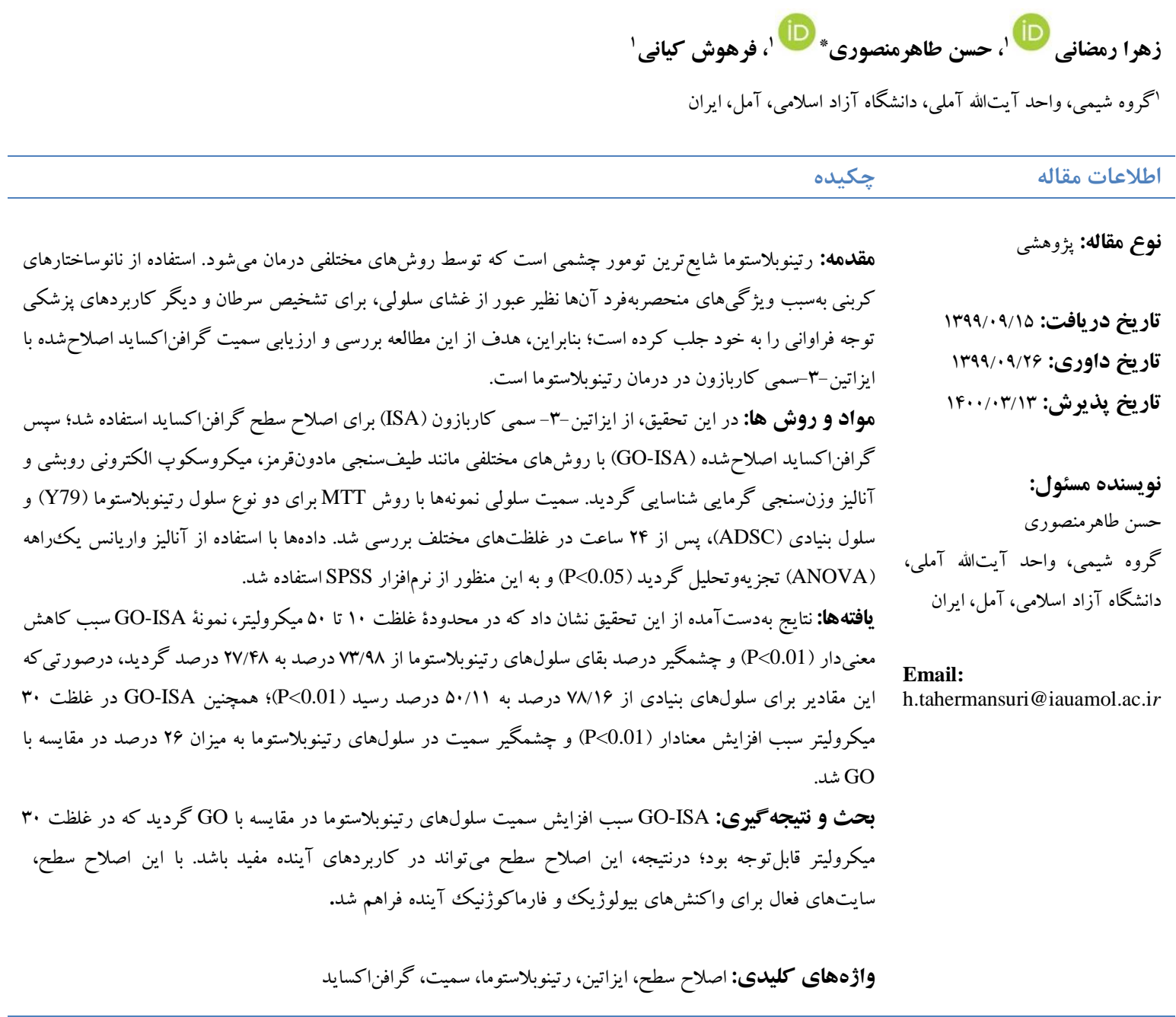

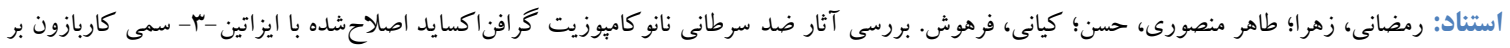

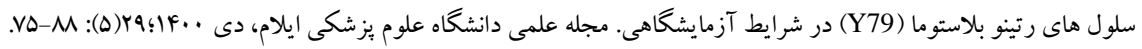


بهعنوان يكك حامل دارورسانى هدفمند براى تحويل

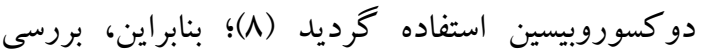
سميت مربوط به آنها براى استفاده از آنها در كاربردهاى بزشكى مهم و ضرورى است. كرافن ورقهاى دوبعدى از اتمهاى كربن در يك تهى بيكربندى ششضلعى است كه اتمها با هيبريد sp2 بههم متصل شدهاند (و). گ خرافن اكسايد نوعى از مشتقات گر افن است كه در آن، گروههاى عاملى اكسيزندار مانند هيدروكسيل، كربو كسيل و إيوكسى حضور دارد. اين نانوساختارهاى كربنى خواص فراوانى نظير رساناى برق عالى، خواص مكانيكى فوقالعاده، ذخيره انرزى و حامل دارو از خود نشان داده است (سا-·(1). تاكنون، برترى و مزيت هاى بسيارى براى كاربرد گر افن و گر افن اكسيد در زمينهُ انتقال دارو بيانشده است؛ اما بعضى معايب وجود دارد كه مىتوان با اصلاح سطح اين نانوساختارها برطرف

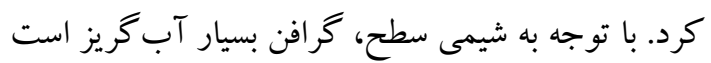
و بهخوبى در آب پيخش نمىشود و براى كاربردهاى بيولوزيكى نياز به سورفاكتانت يا اصلاح سطح دارد. در

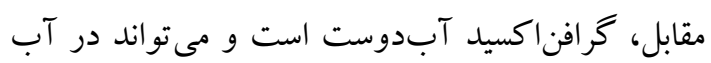
بهورت كلوئيد يايدار ير اكنده شود. بهطور كلى، افزايش حلاليت و انحلال مواد نانويى حامل دارو در دستخاه انتقال دارو، موجب بهبود عملكرد و كاهش سميت اين مواد مى گردد؛ درنتيجه، اصلاح سطح گرافناكسيد مى تواند در بهبود خو اص آن مفيد باشد. دو روش اصلى براى اصلاح سطح گرافن و و كرافن اكسايد وجود دارد: روش اصلاح غير كوالانسى و روش اصلاح كوالانسى (If). روش غير كو الانسى شامل اتصال از طريق نيروهاى واندروالسى، الكترواستاتيك و برهم كنش پِاى-ياى بدون هيج گونه تغييرى در ساختار

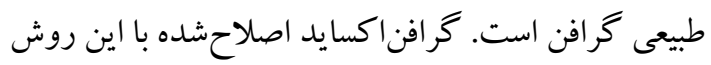
در زمينهاى جذب سورفاكتانت، تعامل با بورفيرينها و مولكول زيستى مانند DNA و يويتيدها استفادهشده است. روش اصلاح كوالانسى شامل واكنش تر كيبات آلى مولى

\section{مقدمه}

رتينوبلاستوما شايعترين تومور جشمى بدخيم در كود كان است و هرساله موارد بسيارى از رتينوبلاستوما در سراسر جهان گزارش مىشود (Y،1). در حال حاضر، رتينوبلاستوما توسط روشهاى مختلفى نظير ليزردرمانى، كرايوترايى، جراحى، برتودرمانى و شيمىدرمانى درمان مىشود (r). هدف از درمان رتينوبلاستوما محافظت از بينايى و كاهش دادن عوارض جانبى است. شيمىدرمانى روش مناسبى براى اين منظور است كه خود شيوههاى كوناگونى دارد (F). با وجود اين، آثار جانبى داروهاى شيمىدرمانى يكك مشكل بزرگك در درمان سرطان است؛ درنتيجه، يافتن و كشف كردن عوامل ضدسرطانى جديد با سميت محدود و مقاومت دارويى كمتر نسبت به سلولهاى سرطانى مهم است (ه). از سوى ديخر، استفاده

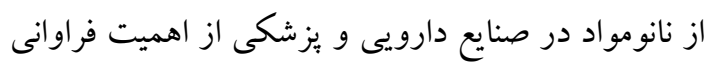
برخوردار است (4). از نانومواد بهسبب ويزگى هاى منحصربهفردى كه در حالت توده در آنها ديده نمىشود، مانند ويز گیىهاى نورى، مغناطيسى، مكانيكى، شيميايى و فيزيكى و توانايى آنها در عبور از غشاى سلولى، براى تشخيص نشانخرهاى زيستى سرطان و ديخر كاربردهاى بزشكى استفاده مى شود (V). در حقيقت، هدف مطالعات جديد، طراحى سيستمهاى جديد درنتيجه اصلاح نانومواد بهمنظور درمان و تشخيص ايمن

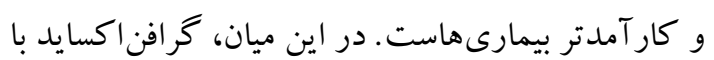
توجه به ويز كىهاى خاص خود نظير سيستم الكترونى مزدوج، فراوانى گرووهاى عاملى حاوى اكسيزن، مساحت سطح بالا و زيستساز گارى، امروزه توجهات بسيارى را براى تحقيقات بنيادى در زمينه كاربردهاى صنعتى و زيست يزشكى به خود جلب كرده است. تلاشهاى فراوانى بهمنظور بررسى كاربردهاى زيست يزشكى كرافن اكسيد اصلاحشده در زمينهاى مختلفى ازجمله حاملهاى دارو، فناورى سلولهاى بنيادى، مهندسى بافت و درمان با نور صورت كرفته است؛ بهنوانمثال، از نانو كاميوزيت اكسيد آهن /كرافناكسايد 
مشتق ايزاتين اصلاح سطح شد كه بهمنظور بررسى صحت

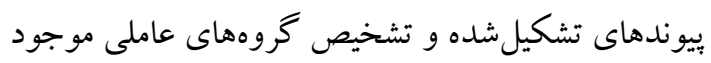
در نانو كاميوريت، از طيفسنجى مادونقرمز، تصاوير

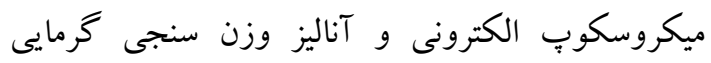

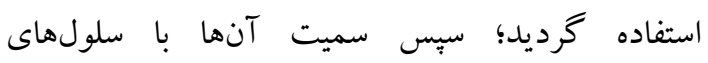
رتينوبلاستوماى جشم (Y79) و بنيادى جربى (ADSC)

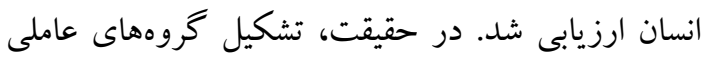

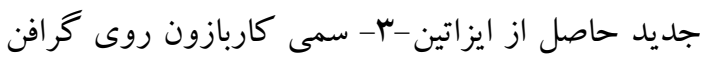
مى تو اند به تغيير سميت آن منجر شود.

\section{مواد و روش ها}

همدُ واكنشخرها و حلالها (تيونيل كلرايد، ايزاتين، سمى كاربازيد، سديم استات، دىمتيل فرماميد، اتانول) از شركت شيميايى Merck و گرافناكسايد با مشخصات (99 درصد، با ضخامت Vتعداد لايههاى ·1-9) از كميانى نتوينو خريدارى

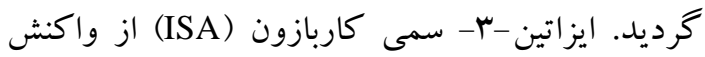
ايزاتين با سمى كاربازيد (·r) فراهم شد. طيفسنجى مادونقرمز (FT-IR) با به كار بردن قرصهاى KBr روى طيف سنج با مدل Thermo Nicolet Nexus 870 FTIR

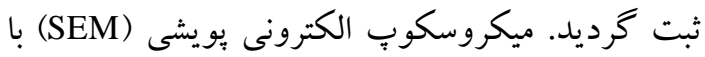
مدل MIRA3||TESCAN-XMU بهمنظور بررسى مورفولوزى تر كيبات استفاده شد. آناليزهاى وزنسنجى كرمايى (TGA) و مشتق وزنسنجى گرمايى (DTG) نمونهها با دستگاه (NETZSCH TG 209 F1 Iris) در فر N2 ( ا درجهُ سانتى گراد بر دقيقه) صورت گرفت.

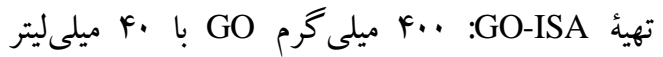

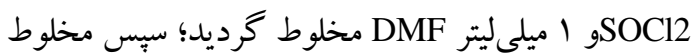
در دماى •V درجة سانتى گر اد به مدت TF ساعت تحت

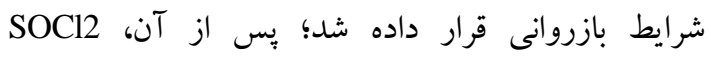

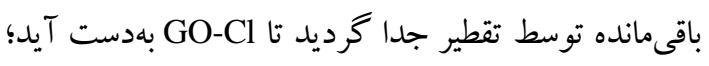

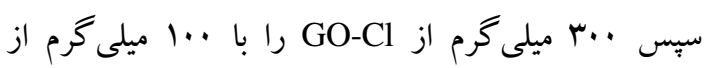

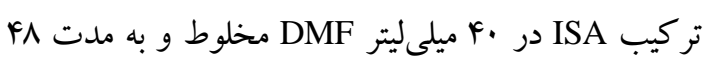

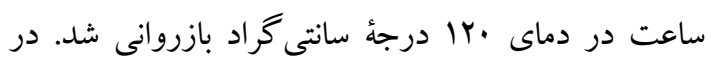

با خروههاى اكسيرن سطح گرافناكسيد است. اصلاح سطح با اين روش بهسهولت انجام مى يذيرد و نانوساختار

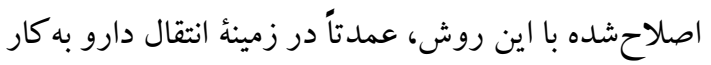

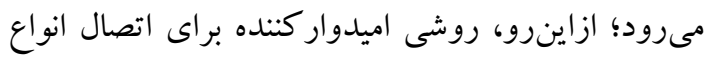

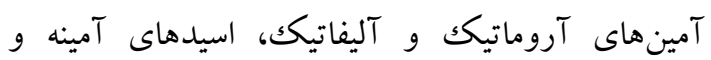
مولكول هاى زيستى، سيلانها، آنزيمها و يليمرها است. در سالهاى اخير، خو اص ضدميكروبى، ضد تشنجى سنى

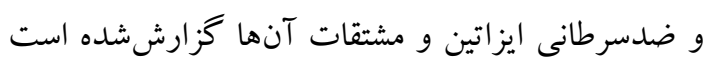

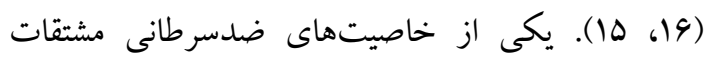

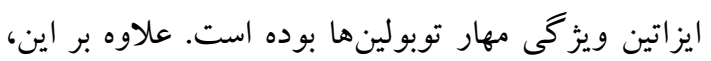

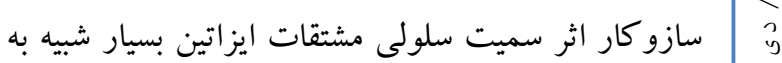

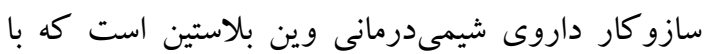

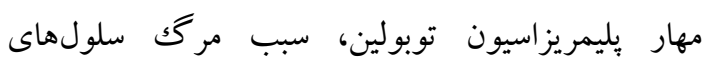
سرطانى مىشوند (IV). علاوه بر اين، در ثئوهشى به بررسى آثار سميت سلولى مشتقات دىبرمو ايزاتين بر

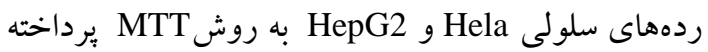
شد. اين مشتقات بر سلولهاى سرطانى كبدى مؤثرتر واقع

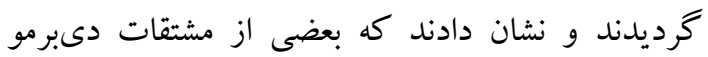
ايزاتين روى سلولهاى سرطانى سميت بالايى دارند كه در ساخت داروهاى شيمىدرمانى مىتواند موردتوجه

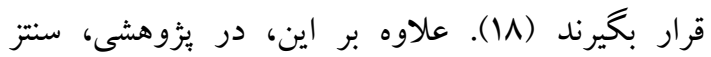
مشتقات ناشى از سييروفلو كساسين و ايزاتين را بهمنظور

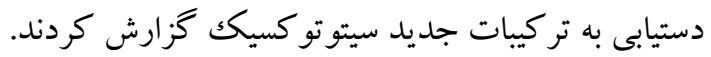

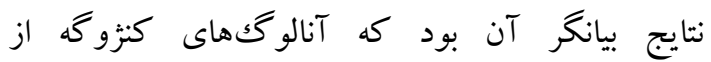
سييروفلو كساسين و مشتقات ايزاتين با روشى ساده قابل

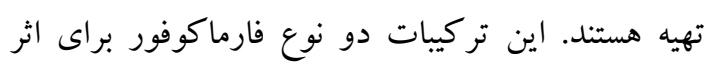

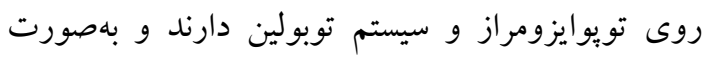

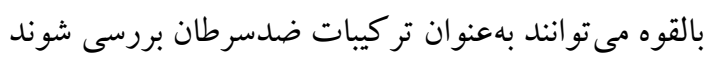

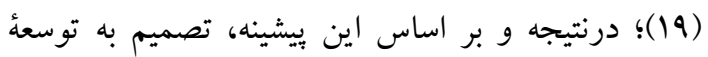

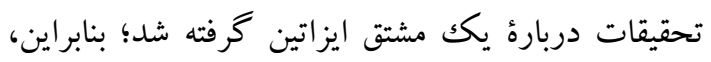
هدف از اين مطالعه بررسى و ارزيابى سميت

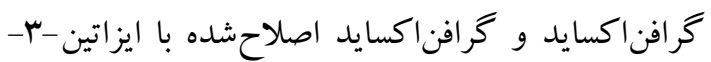

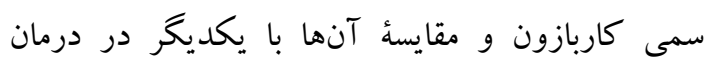

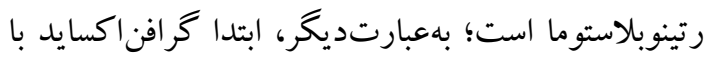


رشد يافتند. براى اين آزمايشها، سلولها در تراكم

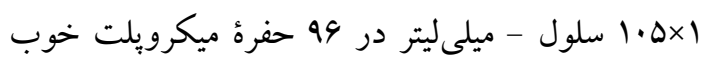

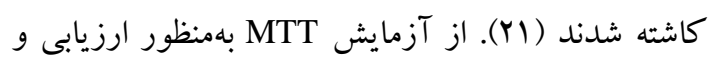

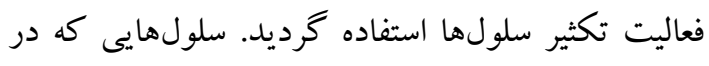
صفحات و9 حفرهاى رشد كردهاند، در معرض نمونهها

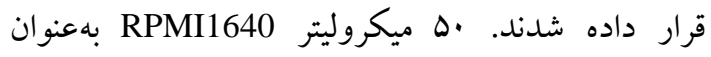
كنترل منفى و •ه ميكروليتر دى متيل سولفو كسيد بهعنوان

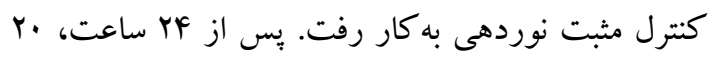

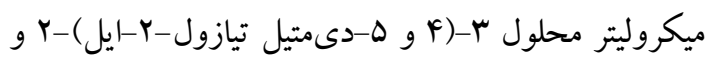

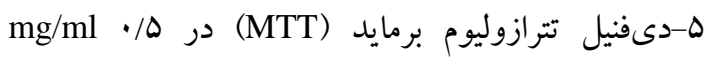

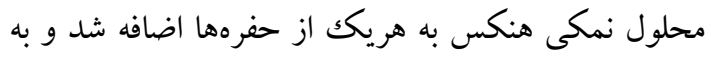

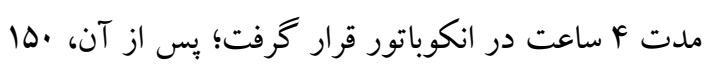

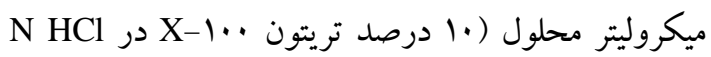
/ • در ايزويرويانول بدون آب) به هر حفره افزوده گرديد.

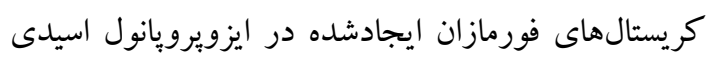

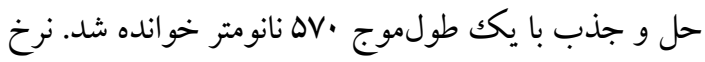

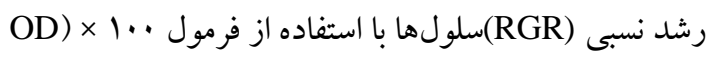

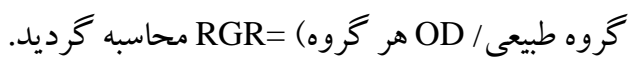
تجزيهوتحليل آمارى دادهها: همهٔ تستها بهصور هرون
ادامه، مخلوط در دماى اتاق سرد گرديد و پيس از جداسازى جندين بار با استون شستوشو داده شد تا ناخالصى ها خارج شوند؛ بِ از آن، بودر سياه بهدست آمده در شرايط خلأد در

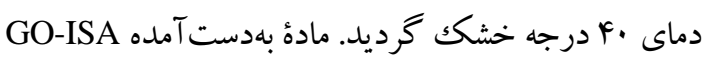

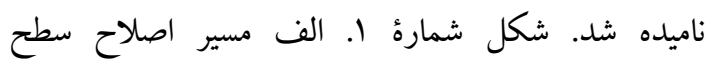
كر افن اكسايد را با ISA نشان مىدهد. تُمارة. مطالعة سلولى: محيط كشت سلولى (RPMI1640)، سرم جنين گوساله، هـ/ • درصد ترييسين با إميلى مولار اتيلن دى آمين تترا استات (EDTA)، استريتومايسين سولفات و ينىسيلين G سديم از GIBCO بهدست آورده

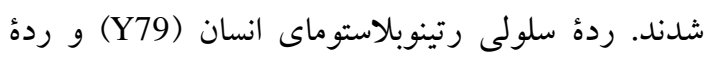
سلولى بنيادى جربى انسان (ADSC) توسط مؤسسه بانكك رتون

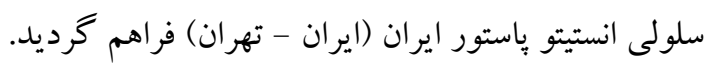

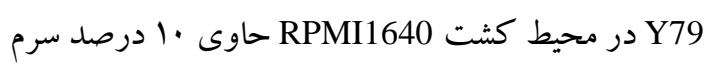

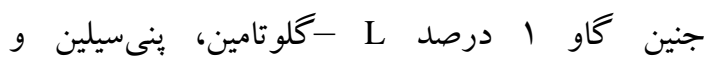
استريتومايسين كشت شدند. گففتى است اين سلولها در

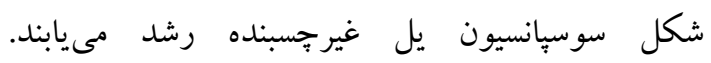
سلولهاى بنيادى ADSC نيز در محيط كشت

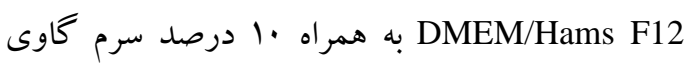

a)

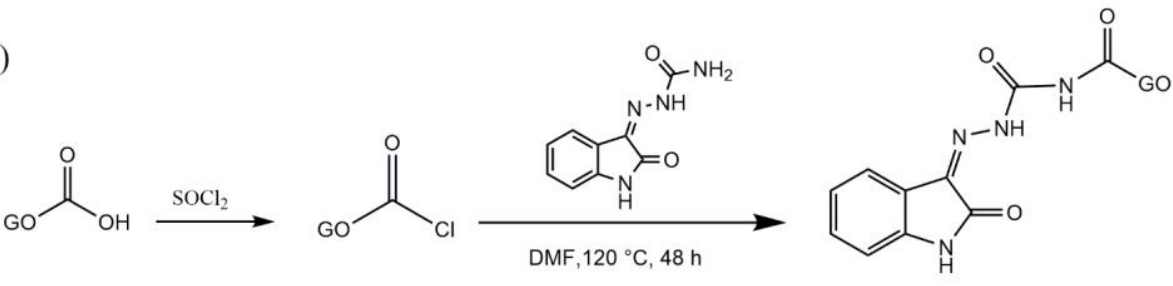

GO

GO-ISA

b)

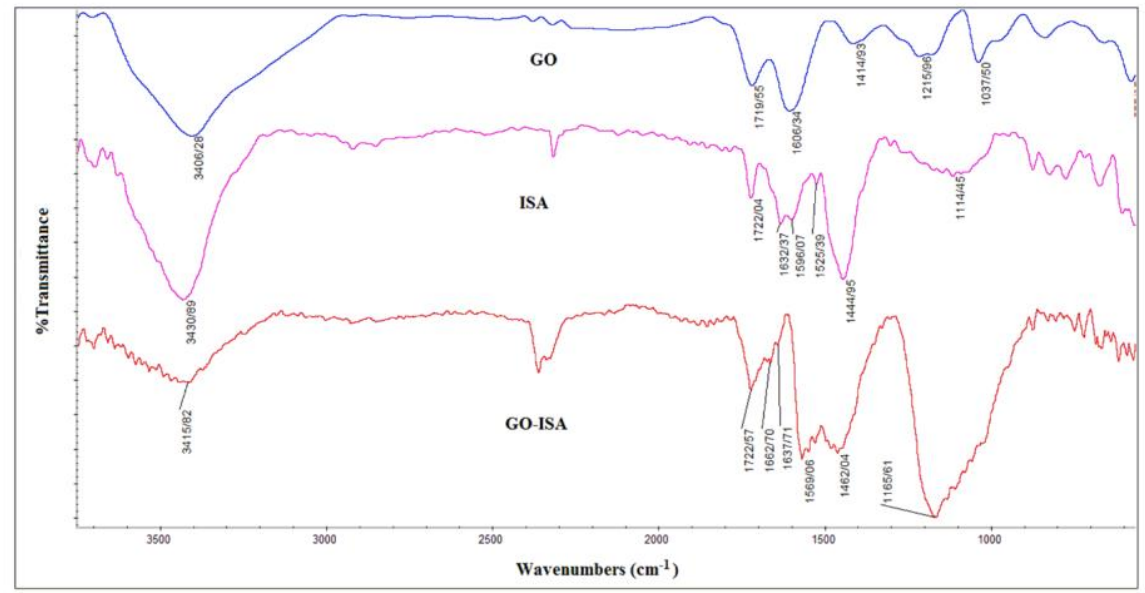

شكل شمارهُ ا. الف. مسير سنتز GO-ISA؛ ب. طيف مادونقرمز (FT-IR) مربوط به نمونهها 
به كربونيل آميد (GO-C=O) نسبت داد. علاوه بر اين، بيككها در 1099cm-1، 149 و 1190 را مىتوان به ترتيب به ارتعاش كششى گروههاى ايمين، حلقهاى آروماتيك و C-O يا C-N مرتبط ساخت كه نشان مىدهد گر افن با ISA مدنظر عاملدار شده است. تصاوير SEM مربوط به كونه كا كه نشاندهنده تغيير ات مورفولوزى سطح گر افن در فرايند اصلاح سطح است، در شكل شماره ب ب نمايش دادهشده است. همانطور كه در شكل شماره r مشاهده مى شود، سطح كر افن اكسيد به شكل صفحهاى و لايهلايه بهصورت يكنواخت و بدون شكستخى است، درحالى كه تصوير

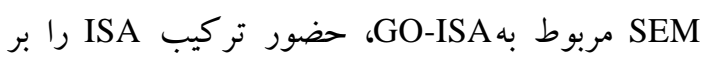
سطح GO نشان مىدهد كه با بيكانهاى زرد نشان دادهشده است؛ درنتيجه، اصلاح سطح GO GO با اين تر كيب تأييد مى گردد.

آناليز وزنسنجى گرمايى (TGA) و وز وزنسنجى تفاضلى (DTG) اطلاعات كمى و مفيدى را درباره اصلاح سطح نانومواد كربنى فراهم مى كند. از آنجاكه دماى تجزئ كرافناكسايد و كروههاى عاملى متصل به آن متفاوت است، كاهش وزن آنها در دماهاى مختلف مىتواند براى

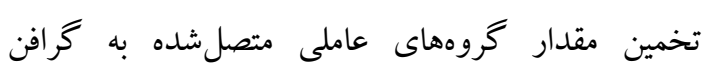

سه تكرار انجام شد. دادههاى بهدست آمده توسط نرمافزار SPSS vol.26 و روش آناليز واريانس يككطرفه (One way ANOVA) تجزيهوتحليل گرديد و تفاوت ميانگينها در سطوح P معنادار در نظر كرفته شد. اطلاعات P P P P 0.010 .05 و دادهها با استفاده از منحنى كاليبراسيون مناسب كاليبره كرديد (Yr)

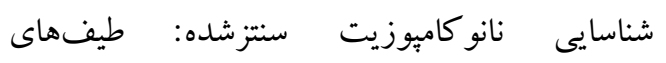
مادونقرمز مربوط به تركيبات مدنظر در شكل شمارهُ نشان دادهشده است. در طيف مربوط به GO، بيككها در

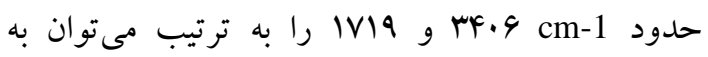
كروههاى OH و OH OH C=O نشاندهنده وجود كروه كربو كسيليك روى روى سطح

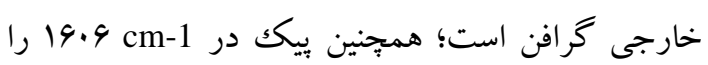
مى توان به كروه C=C نسبت داد. در طيف ISA يبككها

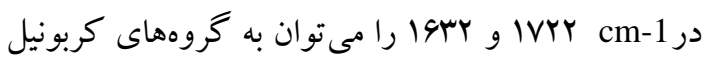
IFFF مربوط ساخت؛ همجنين بيككها در 1099 ISA

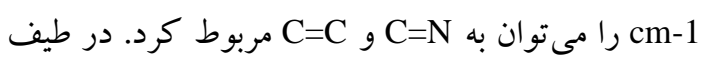
GO-ISA بيكك جديد جذبى در 1994cm-1 را مىتوان

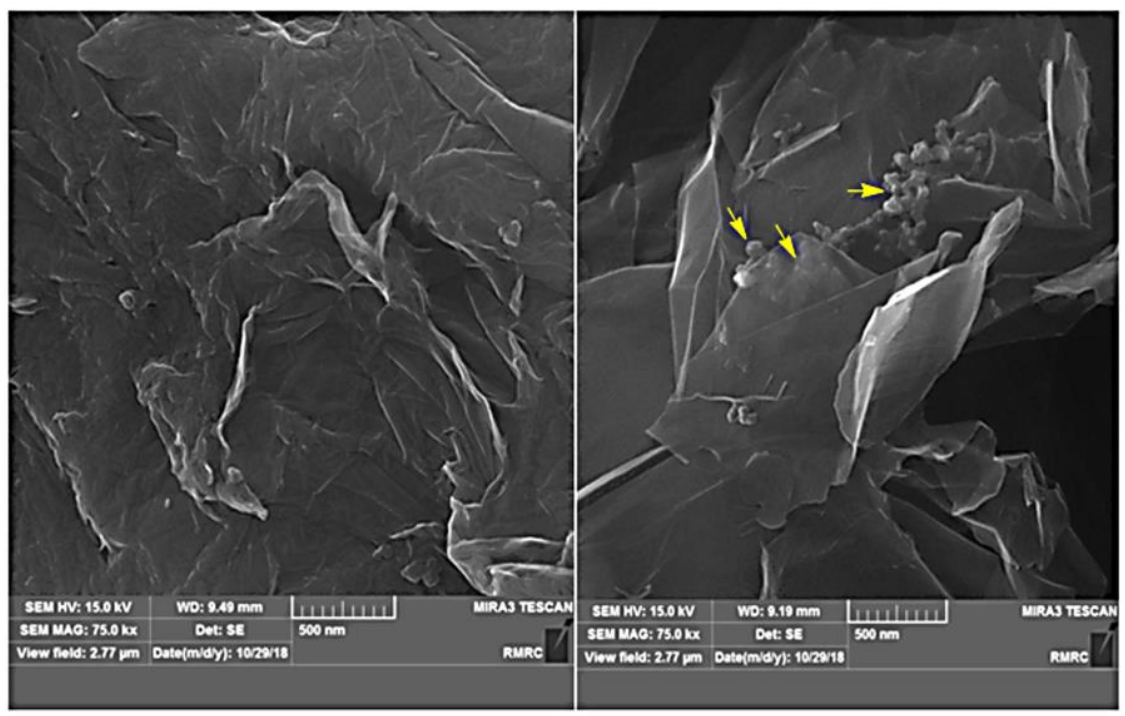

GO

GO-ISA

شكل شمارؤ r. تصاوير SEM مربوط به نمونهها. بيكانهاى زردرنگك ISA را نشان مىدهد كه بر روى صفحة گر افن قرار گرفته است. 
وزن •هQ/P درصد است كه مىتوان به گروههاى عاملى موجود در ISA نسبت داد. منحنى DTG مربوط به ISA هم

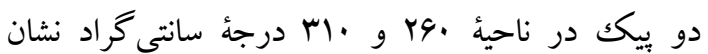
مىدهد كه مىتوان به كرووهاى عاملى ISA مربوط كرد. در نمودار GO-ISA، يك كاهش وزن كسترده از •م تا درجة سانتى گراد با مقدار YF/DF د درصد ديده شد كه مىتوان به گروههاى ISA متصل به گر افن مرتبط دانست؛ ازآنجاكه با نمودار TGA مربوط به ISA مقايسه گرديد. منحنى DTG مربوط به GO-ISA هم يكك بيك جشمخير در •و دوجه دارد كه مربوط به تجزئ نتايج اصلاح سطح GO را با ISA تأييد كرد. اثر GO و GO-ISA بر سميت سلولهاى رتينوبلاستوما

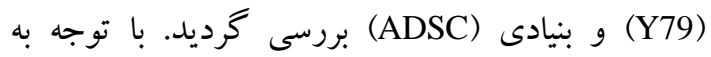
تصاوير مربوط به شكل شمارة Fا، نمونههاى كنترل مربوط به كشت سلولهاى رتينوبلاستوما و بنيادى بر روى سطح TCPS بهخوبى جسبيده شدند و بر روى سطح TCPS كسترش بيدا كردند. تصاوير ديخر مربوط به اثر سلولهاى رتينوبلاستوما و بنيادى در مجاورت GO و GO-ISA است. اين موضوع نشان مىدهد كه نمونهها بهخوبى به سلولهاى رتينوبلاستو ما

نفوذ كردهاند كه در شكل بهخوبى نشان دادهشده است. آناليز MTT يكك روش رنگكسنجى است كه در آن، ماده MTT زردرنگ توسط ميتو كندرى احيا مى گردد كه به ماده بنفشرنگك نامحلول فرمازان منجر مىشود.

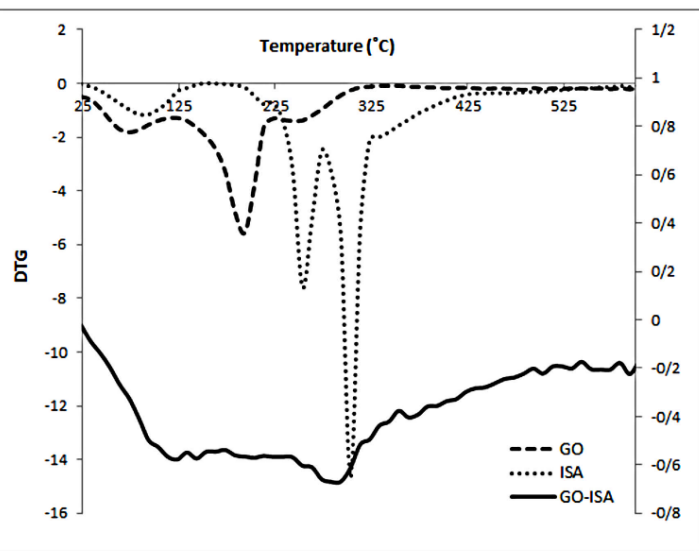

b

شكل شمارؤ r. الف. منحنى TGA و ب. منحنى DTG نمونها در محيط كاز نيتروزن (10 D C /min)

به كاربرده شود. منحنىهاى TGA و TTG مربوط به نمونها در شكل شمارة ب ارائهشده است. همانطور كه ملاحظه مىشود، كاهش وزنهاى قابلتوجه براى تر كيبات نشاندهنده اتصال گروههاى مختلف به كرافن است كه تأييدى بر اصلاح سطح گرافن توسط ISA است. منحنى TGA مربوط به GO سه كاهش وزن دارد. كاهش وزن اول تقريباً در دماى نزديك به · با درجهُ سانتى گراد اتفاق مىافتد كه مربوط به جذب آب بر روى سطح گرافن است. كاهش وزن دوم در دمايى بين ·rا تا •بr درجه اتفاق افتاد و مشخصاً نشانهاى بر تجزئ كروههاى هيدرو كسيل است. كاهش وزن سوم در دماى بالاى . MF. درجه سانتى گراد مشاهده شد كه مىتوان به گروههاى كربو كسيل نسبت داد. مقدار كاهش وزن اول IM/YF درصد، كاهش وزن دوم YQ/VD درصد و كاهش وزن سوم IF/D\& درصد تخمين زده شد. اين نتايج بيانكر وجود گرووههاى اكسيزندار فراوانى روى كر افن اكسايد است. منحنى DTG در شكل شماره س. ب هم شامل سه بيكك در نقاط VD و 191 و . MF درجه است كه به ترتيب به رطوبت، كروههاى هيدروكسيل و كربو كسيل نسبت داده مىشود. در نمودار ISA در محدودهُ ·r إ درجه با مقدار V/I9 درصد و منتسب به كروههاى OH و يا H2O است؛ كاهش وزن دوم در

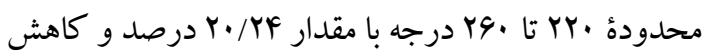
وزن سوم در محدودهُ ·rV تا · .9 درجه و با مقدار كاهش 
درستى از سلولهاى زنده باشد. درواقع، آناليز دار دار ارزيابى دقيق و مهمى از ميزان بقاى سلولها ارائه

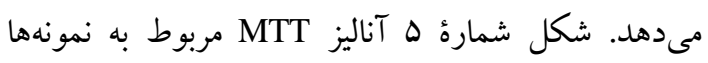

ازآنجاكه سلولهاى زنده و فعال متابوليكى مى تواند

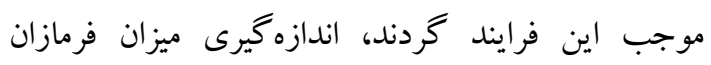
توليدشده به روش طيفسنجى نورى مىتواند تخمين

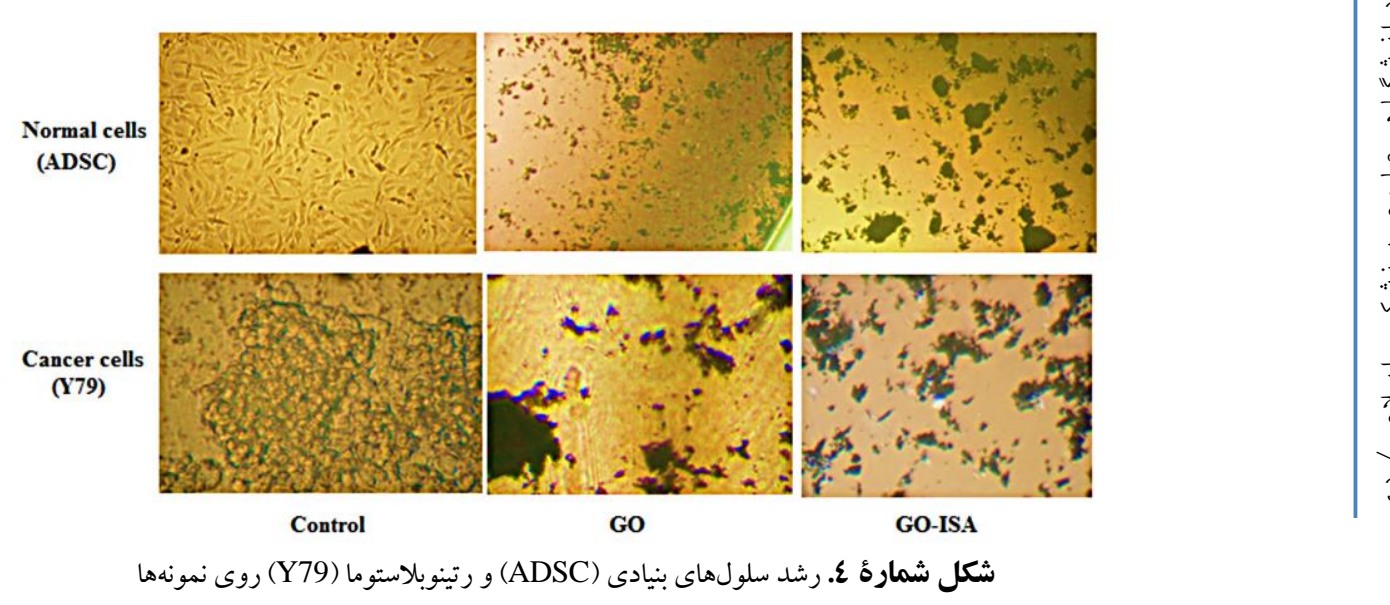

Y79/24h

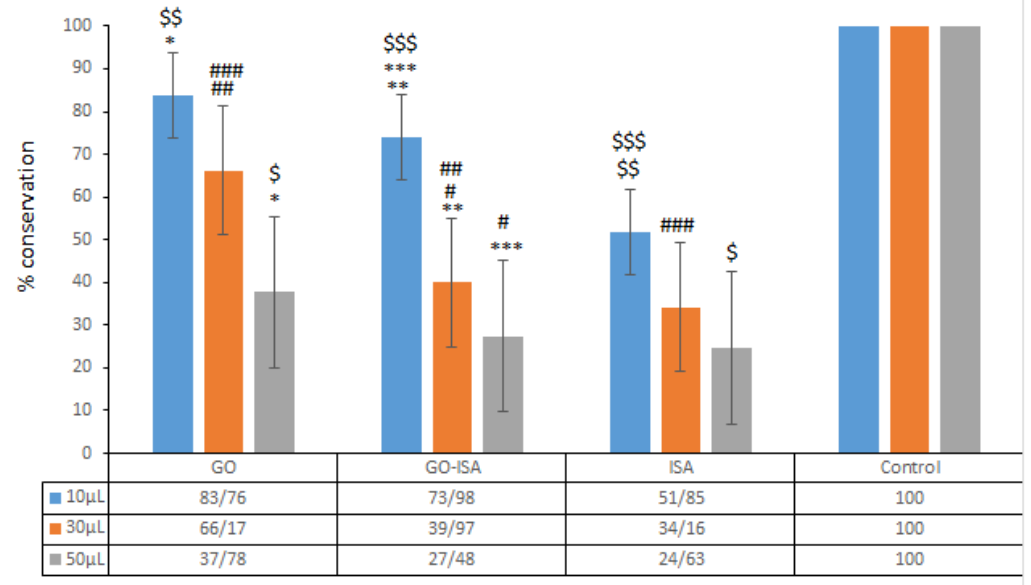

ADSC/24h

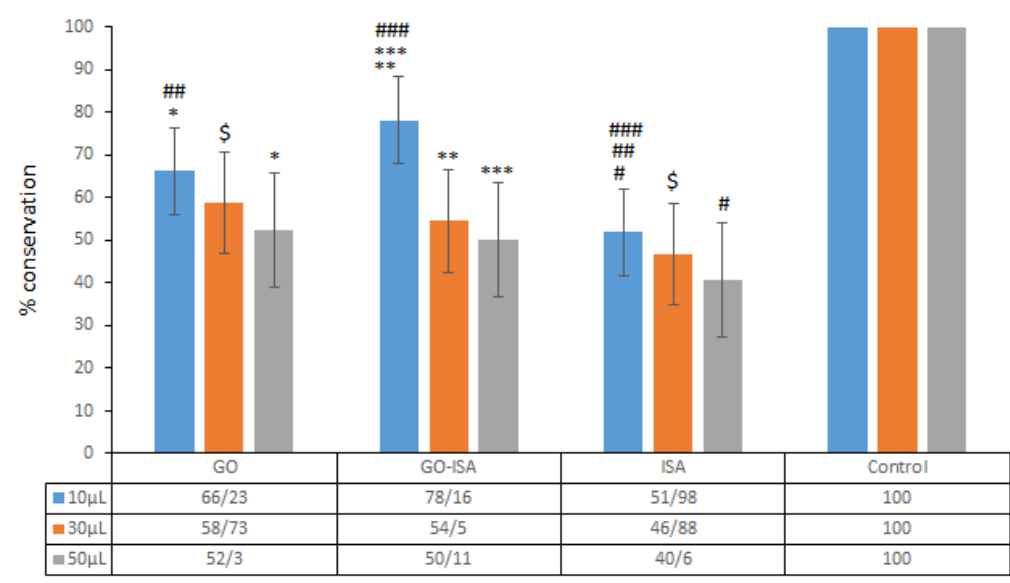

شكل شماره ه. Tناليز MTT مربوط به نمونها در غلظتهاى متفاوت و آثار آنها بر سلولهاى رتينوبلاستوما (Y79) و سلولهاى بنيادى (ADSC) در

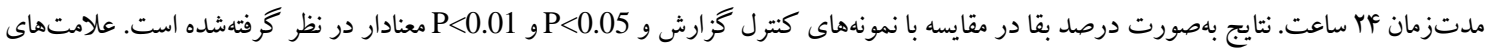

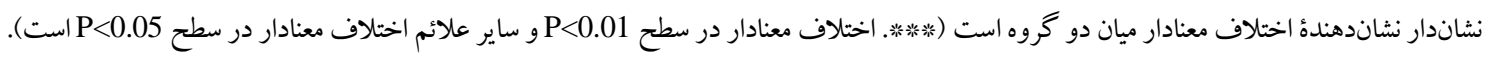


جدول شماره ا. آزمون تحليل واريانس (ANOVA) آثار غلظت نمونهها بر سلولهاى بنيادى (ADSC) و رتينوبلاستوما (Y79)

ميانكين مربعات

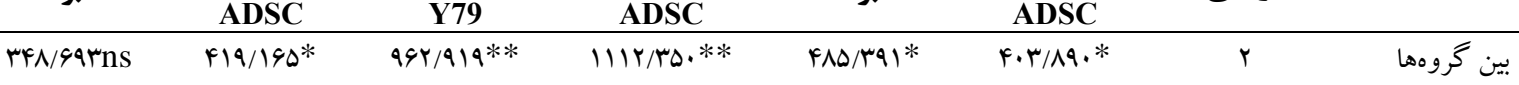

د

كل

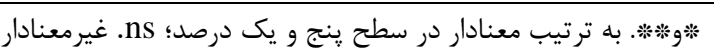

ارائه شده است.

GO- را نشان مى

با توجه به شكل شماره ها و جدول واريانس شماره له ارائه مىدهد. همانطور كه ملاحظه مىشود، ISA

درصد بقاى سلولهاى رتينوبلاستوما در اثر عمل با درصد بقاى سلولها براى هر دو نوع سلول با افزايش GO مقدار نمونها، كاهش يافت؛ همجنين نتايج آناليز معنادارى كاهش يافت ( P>0.05). اين نتيجه زمانى واريانس و توكى نمونها در جدولهاى شماره ا تا Fمأع جدول شمارؤ ז. مقايسٔ آثار غلظت نمونهها روى سلولهاى بنيادى (ADSC) و رتينوبلاستوما (Y79) بر اساس آناليز توكى

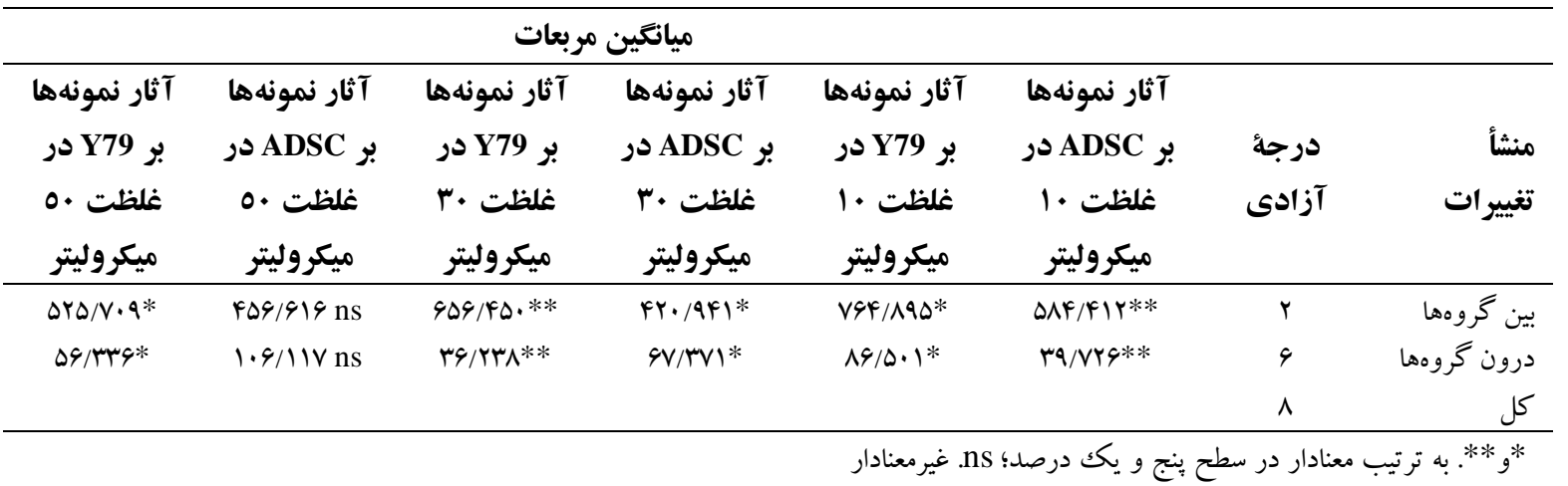

جدول شماره r. آزمون تحليل واريانس (ANOVA) آثار نمونههاى مختلف (ISA ،GO-ISA ،GO) در غلظتهاى مشخص بر سلولهاى بنيادى (YDSC)

\begin{tabular}{|c|c|c|c|c|c|}
\hline \multicolumn{2}{|c|}{ Y79 } & \multicolumn{2}{|c|}{ ADSC } & \multirow{2}{*}{ مقايسة كروهها } & \multirow{2}{*}{ آناليز توكى } \\
\hline P ارزش & ميانكين & P ارزش & ميانكين & & \\
\hline$\cdot / V \Delta F$ & $f_{V} f / \cdot 9$ &.$/ 991$ & av $v / / r$ & GO-ISA با GO & \\
\hline.$/ . k Y$ & $\mathrm{f}_{\mathcal{G}} / \Delta \mathrm{\Delta r}$ & $\cdot / \cdots \wedge$ & ${ }^{a} V \Delta / F Y$ & ISA با GO-ISA & •ا ميكروليتر \\
\hline.$/ \cdot 11$ & $g_{f F} / \cdot V$ & $\cdot \cdots \wedge$ & $\mathrm{b}_{\Delta} 1 / \mathrm{l}$. & GO با ISA & \\
\hline.$/ F r$ & hqu/qf & $\cdot / r V r$ & CGY/FA & GO-ISA با GO & \\
\hline .1 .99 & $i_{F N / 1 \Lambda}$ & $\cdot / 179$ & ${ }^{c d} \Delta Y / V$. & ISA با GO-ISA & •r ميكروليتر \\
\hline$\% r$ & $i_{\mu F / \mu \Lambda}$ & $.1 . \mathrm{rq}$ & $\mathrm{d} \boldsymbol{\mu} / \mathrm{q}$. & GO با ISA & \\
\hline$\cdot / \cdot 19$ & $\mathrm{k} F \wedge / \wedge l$ & $\cdot / r \Delta Q$ & e $01 / 99$ & GO-ISA با GO & \\
\hline$\cdot /$ • & $\mathrm{kl}_{\mathrm{k}}$ & - /OYY & erv/Ir & ISA با GO-ISA & •ه ميكروليتر \\
\hline.$/ .14$ & ${ }^{1} Y Y / \Delta \Delta$ & .1 .91 & etV/FG & GO با ISA & \\
\hline
\end{tabular}


جدول شمارة ع. مقايسة آثار نمونههاى مختلف (GO)، GO-ISA، دور غلظتهاى مشخص بر سلولهاى بنيادى (ADSC) و رتينوبلاستوما (Y79)

\begin{tabular}{|c|c|c|c|c|c|}
\hline \multicolumn{2}{|c|}{ Y79 } & \multicolumn{2}{|c|}{ ADSC } & \multirow{2}{*}{ مقايسة كروهها } & \multirow{2}{*}{ آناليز توكى } \\
\hline P ارزش & ميانكين & P ارزش & ميانكين & & \\
\hline$\cdot / r \cdot V$ & $g_{V / / .9}$ & . MFV & ${ }^{a} V \Delta / / r$ & •ابا ·r ميكروليتر & \\
\hline ./11r & ghar/af & $\cdot / r \Delta G$ & $a b G Y / F A$ & • با • ه ميكروليتر. & GO \\
\hline $.1 \cdot 19$ & $h_{F N / \Lambda I}$ & $\cdot / \cdot \mu \wedge$ & $b_{\Delta 1 / 9 q}$ & •ها · · ميكروليتر & \\
\hline.$/ \cdot 1 r$ & ${ }^{i G / N / \Delta r}$ & $.1 \cdot 41$ & cVD/FY & •ابا ·ـ ميكروليتر & \\
\hline.$/ F r$ & $\mathrm{k}_{F} N / 1 \Lambda$ &.$/ I F V$ & ${ }^{d} \Delta r / v$. & • با • ه ميكروليتر & GO-ISA \\
\hline.$/ \cdot 1$ & j & 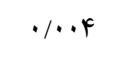 & $d \mu V / I r$ & •ها · · ميكروليتر & \\
\hline - / $4 \Delta Q 9$ & $\mid q F / \cdot V$ & e./rrur & e $\Delta 1 / 1$. & •ابا ·ـ ميكروليتر & \\
\hline ו וT/. & N & e./rqA & efr $\mu / q$. & • با • ه ميكروليتر & ISA \\
\hline $.1 .9 \mathrm{~V}$ & ${ }^{l} Y Y / \Delta \Delta$ & $\mathrm{f} \cdot / \cdot \mathrm{rV}$ & $f_{Y V / F G}$ & •هبا • ا ميكروليتر & \\
\hline
\end{tabular}

حروف انكليسى مشابه نشاندهندة نبود اختلاف معنادار ميان ميانگين بين گروهها است (P>0.05).

ه قابلمشاهده است. با وجود اين، اختلاف معنادارى ميان غلظتهاى ·r و .ه ميكروليتر نبود؛ اما اختلاف ميان

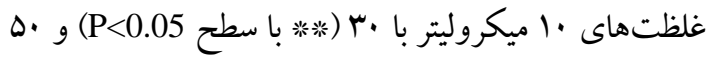

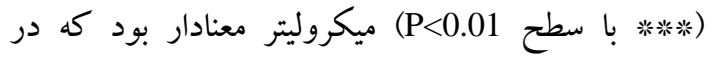
جدول شمارهُ Y ارائه گُرديده است؛ درنتيجه، درصد بقاى سلولهاى بنيادى توسط GO-ISA نسبت به سلولهاى رتينوبلاستوما بيشتر بود. با وجود اين، اثر ISA بر سلولهاى رتينوبلاستوما معنادار نبود (P>0.05)؛ اما روى سلولهاى بنيادى معنادار (\# با سطح P>0.05) بود؛ زيرا اختلاف معنىدار ميان غلظتهاى · ا با •ه ميكروليتر بهدست آمد

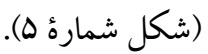

از مقايسٔ نمونههاى GO با GO-ISA به اين نتيجه

مىرسيم كه عاملدار كردن GO با تركيب ISA سبب افزايش سميت يا كاهش بقاى سلولهاى رتينوبلاستوما مىشود و اين در غلظت .ب ميكروليتر بهطور معنادارى (P<0.01) معنادارى ميان GO و GO-ISA وجود داشت (\#)؛ اما اين سميت دربارهٔ سلولهاى بنيادى به علت نبودن اختلاف معنى F). از سوى ديخر، با توجه به جدول شمارهُ س و شكل شماره ه، اختلاف معنادارى در غلظت •ه ميكروليتر ميان GO
است كه مقدار نمونهها از ·. ميكروليتر به •ه ميكروليتر افزايش يافت. همين روند براى سلولهاى بنيادى هم بهدست آمد؛ زيرا درصد بقاى سلولى از سو/49 درصد به r/r (P<0.05). علاوه بر اين، مقادير P مربوط به آناليز توكى براى هر دو نوع سلول نشان داد كه اختلاف معنادارى ميان غلظتهاى ·ل و ·له ميكروليتر براى نمونه GO وجود دارد (جدول شمارهُ Y). در شكل شمارة ها اين اختلاف با علامت

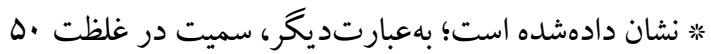
ميكروليتر براى سلولهاى رتينوبلاستوما و بنيادى بهطور

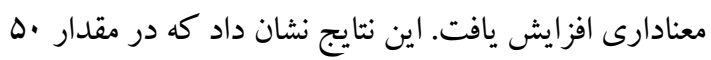
ميكروليتر، تأثير GO بر سلولهاى رتينوبلاستوما بيشتر است و سميت بيشترى براى آنها، در مقايسه با سلولهاى بنيادى، از خود نشان مىدهد. از سوى ديخر، نمونه GO-ISA باعث

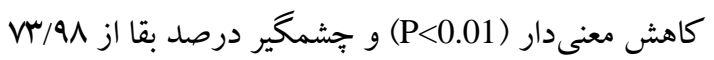
درصد به rV/FA درصد براى سلولهاى رتينوبلاستوما شد

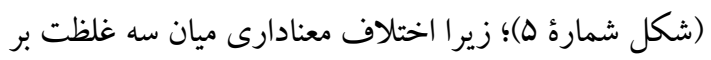

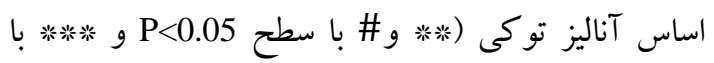
سطح P<0.01) بهدست آمد (جدول شماره Y)؛ همجينين اين مقادير براى سلولهاى بنيادى از VN/19 درصد به 11/ • ه درصد كاهش يافت (P<0.01) كه در شكل شماره 
بهور كلى، اين روشهاى شناسايى اصلاح سطح گرافن را توسط ISA تأييد نمود.

از آنجاكه تغييرات سطح توجه بسيارى از دانشمندان رابه

خود جلب كرده است، در ده سال اخير، تحقيقات

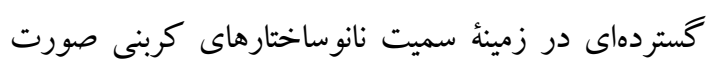
كرفته است (بץ). در يكك تحقيق، سميت سلولى نانولوله لهاى كربنى جنديويوارة: كربو كسيلدار (MWCNT-COOH) بررسى گرديد كه با نينهيدرين و تيواوره اصلاحشده بود (YF). تحقيقات سميت سلولى براى سلولهاى سرطانى سينه

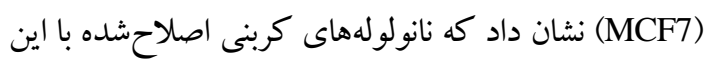
تركيبات (MWCNT-Inden)، سميت بالايى را براى لهاي MWCNT-COOH حدود 90 درصد، در مقايسه با MCF7 كه حدود FV درصد بود، از خود ارائه داد؛ بهعبارتديخر، عاملدار كردن سبب افزايش سميت سلولهاى سرطانى

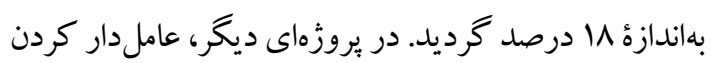

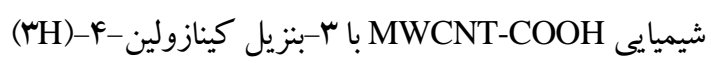
اون بررسى شد. نتايج سلولى براى دو نوع سلول، سلولهاى

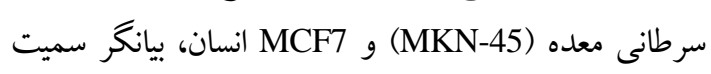

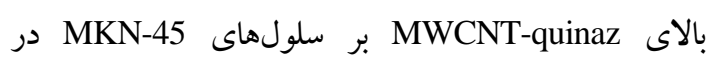
مقايسه با سلولهاى MCF7 بود (YD). سميت نانولولهولهاى بهاى

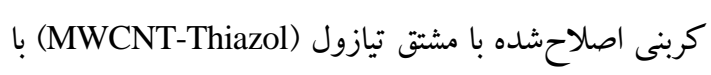
ردههاى سلولى كلئُ جنينى انسان (HEK293) و سرطان

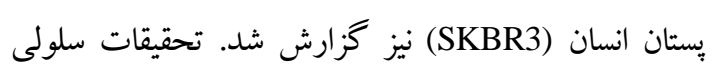

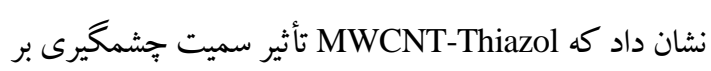
نسبت به HEK293 در غلظتهاى \& تا ه ميكروليتر از خود نشان مىدهد (Y9). علاوه بر اين، عاملدار

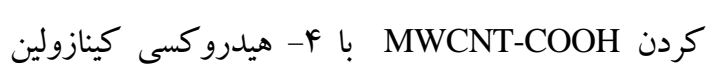
(MWCNT-Quin)

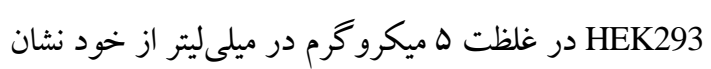
داد (YV). ساختار تر كيبات در زير آمده است.

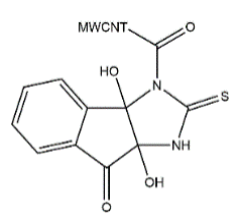

MWCNT-quinaz

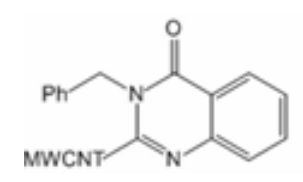

MWCNT-Inden

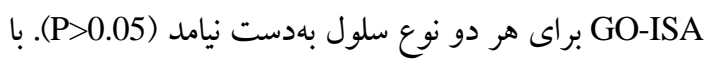

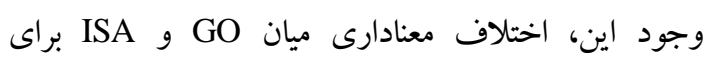

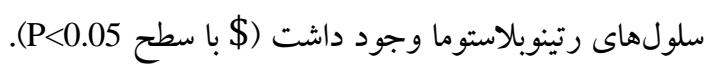

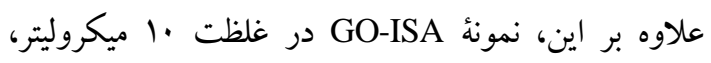
درصد بقاى بيشترى براى سلولهاى بنيادى نسبت به نمونه نهون

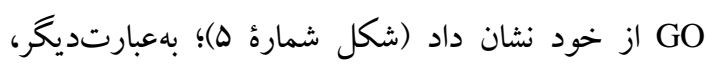

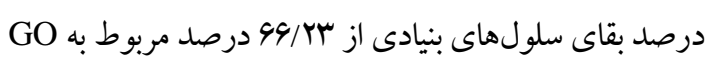

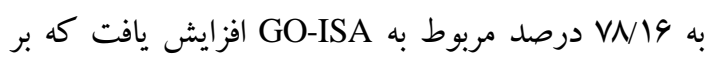
اساس آناليز توكى در جدول شمارة f)، اختلاف معنادارى

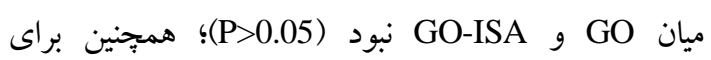

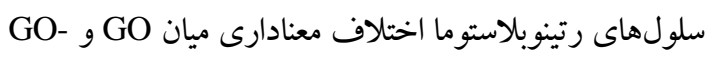
ISA در غلظت • (1 ميكروليتر بهدست نيامد (P>0.05).

\section{بحث و نتيجه كيرى}

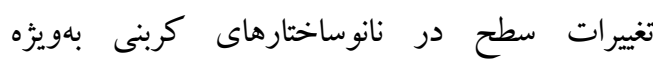
نانو گرافنها نقش مهمى در سميت، كامبوزيتها، تهيئ فيبرها

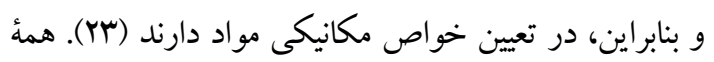
روشهاى موجود براى ايجاد مشتقات شيميايى روى نانوساختارهاى كربن به دو گروه تقسيم مىشوند: اتصال يك برد

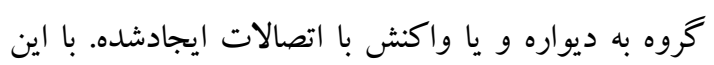

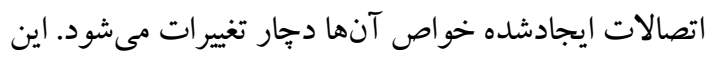
تحقيق شامل واكنش ISA با اتصالات ايجادشده نظير

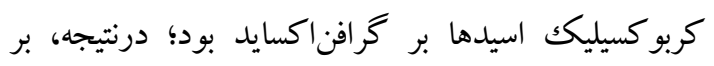
اساس نتايج طيف FT-IR كه حضور گروههاى عاملى ISA كرونى

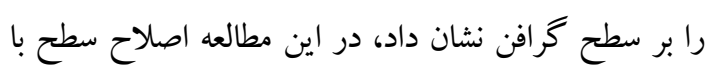
تأتيد شد؛ همجنين تصاوير SEM يكى از شواهد مهم

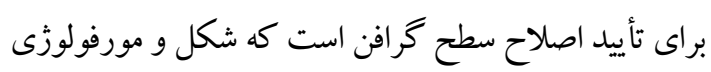
مربوط به تر كيبات مربوطه را ارائه داد. از سوى ديخر، آناليز

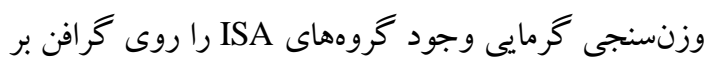
اساس كاهش جرم و دماى تجزئ آنها اثبات كردائ
MWCNT-Thiazol<smiles>CCC(=O)NC1N=C(C)CS1</smiles>

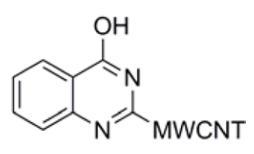

MWCNT-quin 
(Yq) نتايج نشان داد كه افزايش غلظت مو اد كامبوزيتى از

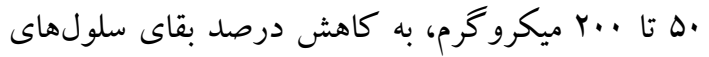

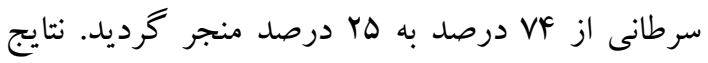

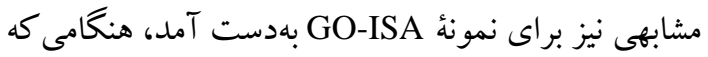
غلظت از · ابه •ه ميكروليتر رسيد. در بزووهى ديخر، آثار

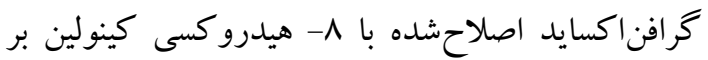
سميت سلولهاى سرطانى و نرمال بِتان بررسى شد. نتايج

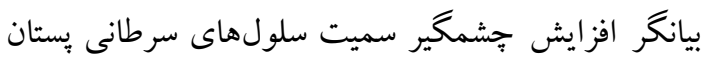

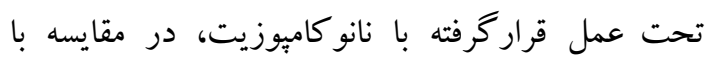
سلولهاى نرمال پِتان بود (·r)؛ همجنين نمونه

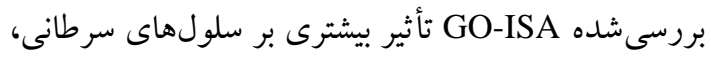
در مقايسه با سلولهاى نرمال داشت. بهطور كلى، بررسى مطالعات بالا نشان مىدهد كه

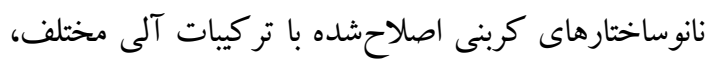

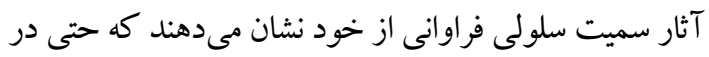
برخى موارد، اين نانومواد آثار سميت بالايى بر سلولهاى

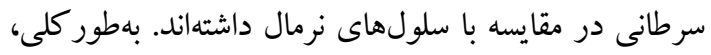
وجود گروههاى عاملى جديد بر نانوساختارهاى كربنى مىتواند باعث تغيير خواص فيزيكى و شيميايى آنها شود.

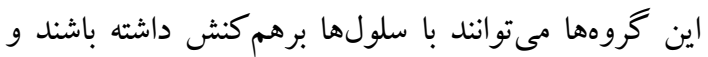
باعث افزايش و يا كاهش سميت آنها گُردند. مشابه با نتايج مطالعات بالا، مطالعٔ حاضر نشان داد كه GO-ISA سنتزده يتانسيل بالايى براى از بين بردن سلولهاى سرطانى

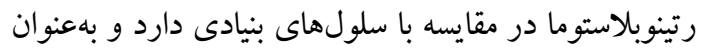
كانديد مناسبى براى درمان و مهار سلولهاى رتينوبلاستوما

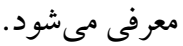

\section{سياس تز ارى}

مقالهٔ حاضر بر گرفته از باياننامؤ مقطع كارشناسى ارشد

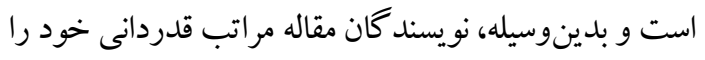
از دانشگاه آزاد اسلامى واحد آيتالله آملى بيان مىدارند.

\section{References}

1. Castillo BV, Kaufman L. Pediatric tumors of the eye and orbit. Pediatr Clin North Am 2003; 50: 149-72. doi.10.1016/S0031-3955(02)00115-3
با مقايسه كردن نتايج يثوهشهاى ارائهشه در بالا و اين يروزه، به اين نتيجه مىرسيم كه درصد سميت سلولهاى سرطانى با اصلاح سطح نانولولههاى كربنى

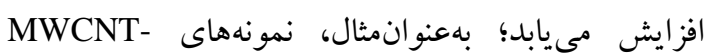
MWCNT- در مقايسه با MWCNT-quinaz و Inden باعث افزايش سميت سلولهاى سرطانى شد؛ بهعبارتديخر، اصلاح سطح در كشتن سلولهاى سرطانى نقش مؤثر داشت. اين موضوع دربارهء GO-ISA هم صدق كرد. وقتى اين نمونه با GO مقايسه گر ديد، سبب افزايش سميت سلول سرطانى شد. علاوه بر اين، نمونههاى MWCNT-Thiazol ميكروليتر سميت قابلتوجهى بر سلولهاى سرطانى در GO- مقايسه با سلولهاى نرمال داشتند، درحالى كه نمونه در غلظت • م ميكروليتر، اثر معنىدار خود را بر سلولهاى سرطانى در مقايسه با نرمال كذاشت. از سوى ديخر، ئزوهشى روى تغييرات سطح و اندازه نانومقياسى گر افن اكسيد در درمان فوتو گرمايى سرطان با استفاده از قدرت ليزر فوقالعاده يايين انجام شد (Y^). طى

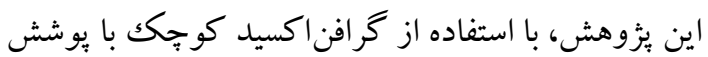
نانو كامبوزيتى بيلىاتيلن كليكول، متوجه شدند كه اندازه و شيمى سطح روى رفتارهاى in vivo (داخل بدن موجود زنده) گرافن تأثير مى گذارد و بهطور قابلتوجهى به بهبود عملكرد آن منجر مىشود. نتايج حاصل از اين تحقيق نشان داد كه شيمى سطح شيميايى و اندازه ذره در عملكرد in vivo كرافن حياتى هستند و نويد استفاده از نانو گرافن بهينهشده براى درمان فتوترمال را مىدهد كه مىتواند بهطور بالقوه، با ساير روشهاى درمانى تر كيب شود تا براى مبارزه عليه سرطان مفيد واقع گردد (YN). در تحقيقى ديخر، يكك مادهُ كاميوزيتى با استفاده از

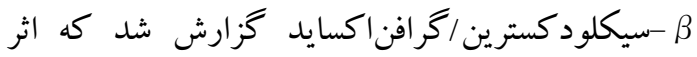
فراوانى بر ردههاى سلولى سرطان دهانهُ رحم داشتند

2. Shields CL, Shields JA. Diagnosis and management of retinoblastoma. Cancer Cont2004; 11: 317-27. doi.10.1177/107327480401100506 
3. Thampi S, Hetts SW, Cooke DL, Stewart PJ, Robbins E, Banerjee A, et al. Superselective intra arterial melphalan therapy for newly diagnosed and refractory retinoblastoma: results from a single institution. Clin Ophthalmol 2013; 7: 981-9. doi.10.2147/OPTH.S43398

4. Anubhav C, Shashi DS. Chemotherapy in retinoblastoma. Int J Therap Rehabil Res 2016; 5: 55-60. doi. 10.5455/ijtrr.000000116

5. Kooshafar Z, Salimi M, Javid A. [Evaluating antitumor effect of a novel hydrazide derivative in mammalian mice model]. Koomesh 2018; 20: 5827. (Persian)

6. Yamanaka YJ, Leong KW. Engineering strategies to enhance nanoparticle mediated oral delivery. $\mathrm{J}$ Biomate Sci Pol Edu 2008; 19:1549-70. doi. 10.1163/156856208786440479

7. Choi YE, Kwak JW, Park JW. Nanotechnology for early cancer detection. Sensors 2010; 10: 428-55. doi.10.3390/s100100428

8. Yang X, Zhang X, Ma Y, Huang Y, Wang Y, Chen Y. Superparamagnetic graphene oxide $\mathrm{Fe} 304$ nanoparticles hybrid for controlled targeted drug carriers. J Mate Chem 2009; 19: 2710-4. doi.10.1039/B821416F

9. Sun Z, James DK, Tour JM. Graphene chemistry synthesis and manipulation. J Phys Chem Let 2011; 2: 2425-32. doi.10.1021/jz201000a

10. Papageorgiou DG, Kinloch IA, Young RJ. Mechanical properties of graphene and graphene based nanocomposites. Prog Mate Sci 2017; 90: 75-127. doi.10.1016/j.pmatsci.2017.07.004

11. Wei J, Zang Z, Zhang Y, Wang M, Du J, Tang X. Enhanced performance of light controlled conductive switching in hybrid cuprous oxide reduced graphene oxide $\mathrm{Cu} 2 \mathrm{o}$ rgo nanocomposites. Opt Let 2017; 42: 911-4. doi.10.1364/OL.42. 000911

12. Lu X, Li L, Song B, Moon K, Hu N, Liao G, et.al. Mechanistic investigation of the graphene functionalization using p-phenylenediamine and its application for supercapacitors. Nano Ene 2015; 17: 160-70. doi.10.1016/j.nanoen.2015.08.011

13. Huang J, Jacobsen J, Larsen SW, Genina N, Weert M, Mullertz A, et al. Graphene oxide as a functional excipient in buccal films for delivery of clotrimazole effect of molecular interactions on drug release and antifungal activity in vitro. Int $\mathbf{J}$ Pharm 2020; 589: 119811. doi.10.1016/j.ijpharm. 2020.119811

14. Chouhan A, Mungse H P, Khatri OP. Surface chemistry of graphene and graphene oxide a versatile route for their dispersion and tribological applications. Adv Coll Int Sci 2020; 283: 102215. doi.10.1016/j.cis.2020.102215

15. Pandeya SN, Smitha S, Jyoti M, Sridhar SK. Biological activities of isatin and its derivatives. Acta Pharm2005; 55:27-46.

16. Vine KL, Matesic L, Locke JM, Ranson M, Skropeta D. Cytotoxic and anticancer activities of isatin and its derivatives a comprehensive review from 2000-8. Ant Age Med Chem 2009; 9: 397414.

17. Jordan MA. Mechanism of action of antitumor drugs that interact with microtubules and tubulin. Curr Med Chem Ant Age2002; 2:1-17. doi.10.2174/1568011023354290
18. Shokrzadeh M, Emami S, Amirzadeh M, Modanloo M. [Cytotoxic effects of Dibromoisatin derivatives on hela and hepg2 cell lines using $\mathrm{mtt}$ assay]. Mazandaran Uni Med Sci 2017; 27:24-31. (Persian)

19. Emami S, Raeesi M. [Synthesis of Ciprofloxacin isatin conjugates as potential cytotoxic agents]. J Mazandaran Uni Med Sci 2016; 26: 161-9. (Persian)

20. Pandeya SN, Tripathi K, Kulshreshtha S. Synthesis and antifungal activity of isatin3 semicarbazone. Asian J Chem 2009; 21: 3367-70.

21. Haydarikashl S, Entezari M, Hekmati M, Solaimani S. [Functionalization of carboxylated multi walled nanotubes with diazo compounds of aromatic amins and anti cancer study on sw742 cell line by invitro conditions]. J Ilam Uni Med Sci 2013; 21:138-43. (Persian)

22. Haydari kashl S, Tahermansori H, Atghaee M, Biazar E, Saifipour F, Avazpour M, et al. [Evaluation of multi walled carbon nanotubes cytotoxicity elements oxathiazole and phenyl hydrazine derivative was prepared by microwave]. J Ilam Uni Med Sci2013; 20: 25564. (Persian)

23. Jastrzebska A M, Kurtycz P, Olszyna AR. Recent advances in graphene family materials toxicity investigations. J Nanopart Res 2012; 14:1320. doi.10.1007/s11051-012-1320-8

24. Tahermansouri H, Abedi E. One pot functionalization of short carboxyl multi walled carbon nanotubes with ninhydrin and thiourea via Microwave and thermal methods and their effect on the MKN-45 and MCF7cancer cells. Full Nanotub Carbon Nanostru2014; 22: 834-44. doi.10.1080/1536383X.2012.742428

25. Tahermansouri H, Mirosanloo A. One pot and three component functionalization of short multi walled carbon nanotubes with isatoic anhydride and benzyl amine and their effect on the MKN-45 and MCF7 cancer cells. Fullerenes, Nanotub Carbon Nanostruc 2015; 23: 500-8. doi.10.1080/1536383X.2013.868440

26. Tahermansouri H, Islami F, Gardaneh M, Kiani F. Functionalisation of multiwalled carbon nanotubes with thiazole derivative and their influence on SKBR3 and HEK293 cell lines. Mate Technol 2016; 31: 371-6. doi. $10.1179 / 1753555715$ Y.0000000062

27. Tahermansouri H, Mirosanloo A, Heidarikeshel S, Gardaneh M. Synthesis characterization and toxicity of multi walled carbon nanotubes functionalized with 4hydroxyquinazoline. Carbon Let2016; 17: 45-52. doi. 10.5714/CL.2016.17.1.045

28. Yang K, Wan J, Zhang S, Tian B, Zhang Y, Liu Z. The influence of surface chemistry and size of nanoscale graphene oxide on photothermal therapy of cancer using ultra low laser power. Biomaterials 2012; 33: 2206-14. doi.10.1016/j.biomaterials. 2011.11.064

29. Samuel M S, Selvarajan E, Subramaniam K, Mathimani T, Seethappan S, Pugazhendhi A Synthesized $\beta$-cyclodextrin modified graphene oxide composite for adsorption of cadmium and their toxicity profile in cervical cancer cell lines. Proce Biochem 2020; 93: 28-35. doi. 10.1016/j.procbio.2020.02.014 
30. Kheiltash F, Parivar K, Hayati Roodbari N, Sadeghi B, Badiei A. [Effects of 8hydroxyquinoline coated graphene oxide on cell death and apoptosis in MCF-7 and MCF-10 breast cell lines]. Iran J Bas Med Sci 2020; 23:871-8. (Persian) 